\title{
Early Identification of the Maternal, Placental and Fetal Dialog in Gestational Diabetes and Its Prevention
}

\author{
Amir Naeh 1,2,*(D), Esther Maor-Sagie ${ }^{1,2}$, Mordechai Hallak ${ }^{1,2}$ and Rinat Gabbay-Benziv 1,2 (D) \\ 1 Department of Obstetrics and Gynecology, Hillel Yaffe Medical Center, Hadera 38100, Israel; \\ estigal02@yahoo.com (E.M.-S.); mottih@hy.health.gov.il (M.H.); gabbayrinat@gmail.com (R.G.-B.) \\ 2 The Rappaport Faculty of Medicine, Technion-Israel Institute of Technology, Haifa 32000, Israel \\ * Correspondence: amir_naeh@outlook.com; Tel.: +972-4-7748224
}

check for

updates

Citation: Naeh, A.; Maor-Sagie, E.;

Hallak, M.; Gabbay-Benziv, R. Early Identification of the Maternal,

Placental and Fetal Dialog in

Gestational Diabetes and Its

Prevention. Reprod. Med. 2022, 3,

1-14. https://doi.org/10.3390/

reprodmed 3010001

Academic Editor: Berthold

Huppertz

Received: 14 November 2021

Accepted: 15 December 2021

Published: 23 December 2021

Publisher's Note: MDPI stays neutral with regard to jurisdictional claims in published maps and institutional affiliations.

Copyright: (C) 2021 by the authors. Licensee MDPI, Basel, Switzerland. This article is an open access article distributed under the terms and conditions of the Creative Commons Attribution (CC BY) license (https:// creativecommons.org/licenses/by/ $4.0 /)$.

\begin{abstract}
Gestational diabetes mellitus (GDM) complicates between 5 and 12\% of pregnancies, with associated maternal, fetal, and neonatal complications. The ideal screening and diagnostic criteria to diagnose and treat GDM have not been established and, currently, diagnostic use with an oral glucose tolerance test occurs late in pregnancy and produces poor reproducibility. Therefore, in recent years, significant research has been undertaken to identify a first-trimester biomarker that can predict GDM later in pregnancy, enable early intervention, and reduce GDM-related adverse pregnancy outcomes. Possible biomarkers include glycemic markers (fasting glucose and hemoglobin A1c), adipocyte-derived markers (adiponectin and leptin), pregnancy-related markers (pregnancyassociated plasma protein-A and the placental growth factor), inflammatory markers (C-reactive protein and tumor necrosis factor- $\alpha$ ), insulin resistance markers (sex hormone-binding globulin), and others. This review summarizes current data on first-trimester biomarkers, the advantages, and the limitations. Large multi-ethnic clinical trials and cost-effectiveness analyses are needed not only to build effective prediction models but also to validate their clinical use.
\end{abstract}

Keywords: gestational diabetes; biomarkers; early prediction; pregnancy complications

\section{Introduction}

Gestational diabetes mellitus (GDM) is defined as a condition in which carbohydrate intolerance develops during pregnancy [1]. GDM complicates between 5 and 12\% of pregnancies, with prevalence varying significantly by region, race, and diagnostic criteria [2].

GDM is associated with maternal, fetal, and neonatal complications [3,4], as well as with a significant risk to develop type 2 diabetes mellitus (T2DM) and cardiovascular complications in the future for both the mother and her offspring [5,6].

Despite decades of research, the ideal screening and diagnostic criteria to diagnose and treat GDM have not been established and are still under debate [7,8]. Currently, the gold standard for diagnosing GDM is the oral glucose tolerance test (OGTT), which involves fasting, is time-consuming and exacting for both patients and physicians, and produces poor reproducibility [9]. Furthermore, universal screening occurs between 24 to 28 weeks of gestation, leaving little time for intervention and treatment once GDM is diagnosed.

Therefore, in recent years, significant research was undertaken to develop a simple, rapid, non-fasting blood test that could identify women with GDM. Identifying such a firsttrimester biomarker that predicts GDM in pregnancy will enable not only the nullification for the need for universal screening in all pregnant women but also the possibility of early intervention to improve pregnancy and long-term outcomes.

The purpose of this review is to discuss the importance of early GDM prediction, to summarize current data on first-trimester biomarkers which have been evaluated in recent years as potential predictors of GDM, and to illustrate future directions and research. 


\section{Pathophysiology of GDM}

The pathogenesis of GDM is multifactorial and complex. During pregnancy, insulin sensitivity decreases by up to $70 \%$ in the third trimester, with placental hormones significantly contributing to this process [10]. GDM develops when a relative pancreatic $\beta$-cell dysfunction leads to insufficient maternal insulin levels to sustain increasing demands. The exact cause for this $\beta$-cell dysfunction is unclear, with described mechanisms includ inflammatory pathways, genetic abnormalities, hormone-mediated and autoimmune disorders [11].

GDM predisposes both the mother and baby to a wide variety of complications during pregnancy but also in the postpartum period and later in life. During pregnancy, women with GDM are at a higher risk for hypertensive disorders of pregnancy [12]. Regarding labor and delivery, GDM is associated with significantly higher rates of induction of labor, operative delivery, obstetric anal sphincter injury, and cesarean section [13,14]. Later in life, up to $70 \%$ of women with GDM will develop T2DM within 25 years after pregnancy, with higher rates of metabolic syndrome and cardiovascular disease $[6,15,16]$.

The fetus of the mother with GDM has an increased risk for macrosomia, shoulder dystocia, and birth trauma [17]. In the postpartum period, the neonate is at risk for neonatal hypoglycemia and hyperbilirubinemia $[18,19]$. Studies have demonstrated that exposure to maternal diabetes in utero affects fetal programming and is associated with significant morbidities later in life, including childhood and adult-onset obesity and diabetes, as well as cardiovascular complications $[5,20]$.

\section{Importance of GDM Prediction}

The Hyperglycemia Adverse Pregnancy Outcomes (HAPO) study demonstrated that the relationship between adverse outcomes and maternal glucose levels is a continuum and therefore already exists even below the threshold that is considered diagnostic for GDM [19]. Similarly, recent data suggest that a 3-h OGTT with only one pathological value is associated to risks comparable to those of women with two or more pathological values on OGTT, thus regarded as GDM [21,22]. Multiple studies have shown that proper diagnosis and intervention of GDM with lifestyle modifications (dietary and physical activity) or pharmacological treatment can significantly reduce the frequency of adverse pregnancy outcomes [23,24]. Therefore, early prediction of GDM has the potential to detect and treat women earlier in pregnancy, limit the fetal and maternal exposure to impaired glucose metabolism, decrease pregnancy complications, and perhaps affect fetal programming, thereby reducing the prevalence of T2DM for both the mother and offspring [25].

\section{Predicting GDM by Maternal Risk Factors}

Clinical and historic risk factors can be used individually or in combination to identify women with an increased risk of developing GDM (Table 1).

Table 1. Clinical risk factors with corresponding odds ratios for gestational diabetes mellitus.

\begin{tabular}{lc}
\hline \multicolumn{1}{c}{ Risk Factor } & Odds Ratio \\
\hline 1. Ethnicity: Asian, Middle Eastern, Hispanic, Latino, African American, and & $2.32[26]$ \\
Indigenous & $3.54[27]$ \\
2. Maternal age $\geq 35$ years & $2.14[28]$ \\
3. Pre-pregnancy BMI $>25 \mathrm{~kg} / \mathrm{m}^{2}$ & $2.32[29]$ \\
4. Polycystic ovary syndrome & $5.9[26]$ \\
5. GDM in a previous pregnancy & $1.54[26]$ \\
6. Previous delivery of macrocosmic baby (birth weight $>4000$ gr or & $1.36[26]$ \\
>90th centile) & $1.13[30]$ \\
7. Family history of diabetes (1st degree relative) & $1.26[31]$ \\
8. Multiple pregnancy & \\
9. Assisted reproductive technology &
\end{tabular}

BMI—body mass index and GDM—gestational diabetes mellitus. 
These include, among others, advanced maternal age, increased body mass index (BMI), ethnicity, family history of diabetes, and history of GDM or macrosomia in a previous pregnancy [26-31]. However, while some studies showed that a combination of maternal risk factors can allow for successful early screening [32,33], others have demonstrated minimal efficacy $[34,35]$ and are limited by variation between ethnic groups in the association of different risk factors (e.g., BMI), alongside a lack of significant external validation in clinical practice. More importantly, these models are targeted mostly to identify women who have some degree of glucose intolerance that preceded pregnancy rather than predicting the development of GDM later in pregnancy.

\section{Predicting GDM Using Individual Biomarkers}

Due to the increased prevalence of GDM and the poor reproducibility of the OGTT, extensive research in recent years attempted to identify biomarkers that could aid in GDM prediction. In fact, a recent review found 589 different biomarkers evaluated for association with GDM [36]. Tested biomarkers include glycemic-related markers, adipokines, growth factors, pregnancy-related proteins, inflammatory markers, different hormones, coagulation factors, nucleic acids, glycoproteins, complement components, and many others (Figure 1).

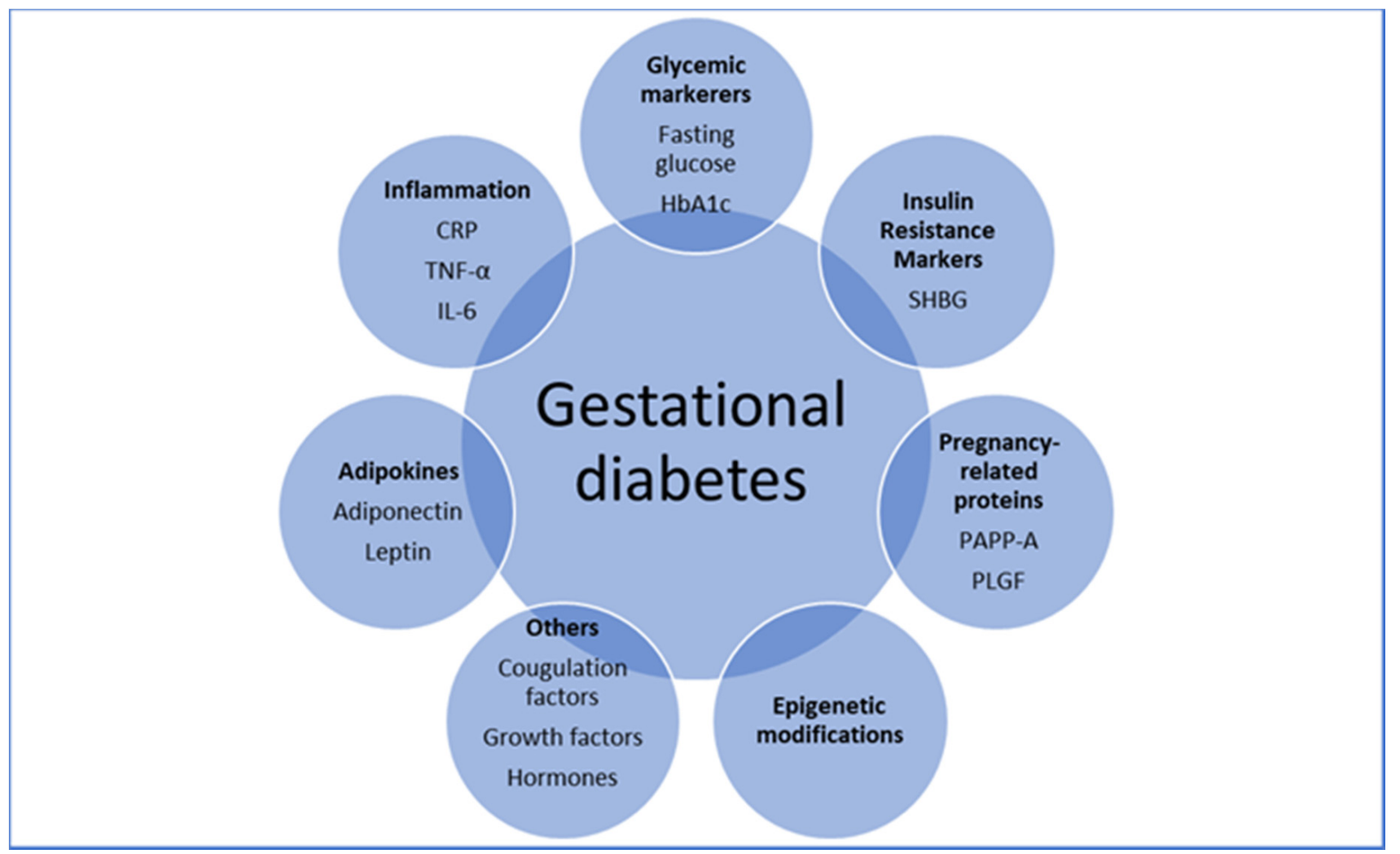

Figure 1. Overview of tested biomarkers. CRP-C-reactive protein; IL-6 -interleukin 6; PAPPA-pregnancy-associated plasma protein A; PLGF-placental growth factor; SHBG—sex hormonebinding globulin; and TNF- $\alpha$-tumor necrosis factor $\alpha$.

In this review, we chose to focus on the main biomarkers that were evaluated as GDM predictors (Table 2). 
Table 2. Potential biomarkers for gestational diabetes mellitus.

\begin{tabular}{|c|c|c|}
\hline Biomarker & Function & Suggested Involvement in GDM Pathophysiology \\
\hline Adiponectin & $\begin{array}{l}\text { Modulation of glucose and fatty acid metabolism. } \\
\text { Involvement in inflammation, apoptosis, and } \\
\text { angiogenesis. }\end{array}$ & $\begin{array}{l}\text { Low levels associated with decreased insulin } \\
\text { sensitivity and GDM }\end{array}$ \\
\hline Leptin & $\begin{array}{l}\text { Regulation of energy balance and expenditure. Role } \\
\text { in hormone regulation and immunity. }\end{array}$ & $\begin{array}{l}\text { High leptin levels cause hyperinsulinemia and } \\
\text { increase insulin resistance }\end{array}$ \\
\hline PAPP-A & $\begin{array}{l}\text { Increase bioavailability of IGF-1 and promotes } \\
\text { somatic growth. Involvement in wound healing and } \\
\text { bone remodeling. }\end{array}$ & $\begin{array}{l}\text { Decreased levels contribute to an increase in } \\
\text { insulin resistance }\end{array}$ \\
\hline PLGF & $\begin{array}{l}\text { Vascular endothelial growth factor-like protein. Role } \\
\text { in angiogenesis and placentation. }\end{array}$ & $\begin{array}{l}\text { High PLGF levels promote the abnormal vascular } \\
\text { network in placentas of GDM pregnancies }\end{array}$ \\
\hline TNF- $\alpha$ & $\begin{array}{c}\text { Inflammatory cytokine involved in the regulation of } \\
\text { immune cells, inflammation, and } \\
\text { autoimmune diseases. }\end{array}$ & $\begin{array}{c}\text { Increased levels impair insulin signaling and } \\
\text { beta-cell function, leading to insulin resistance } \\
\text { and GDM }\end{array}$ \\
\hline CRP & $\begin{array}{l}\text { Acute-phase reactant. Role in tissue injury, } \\
\text { inflammation, and infection. }\end{array}$ & $\begin{array}{l}\text { High levels associated with insulin resistance and } \\
\text { systemic inflammation }\end{array}$ \\
\hline IL-6 & $\begin{array}{l}\text { Circulating inflammatory cytokine. Role in immune } \\
\text { response regulation, inflammation, } \\
\text { and hematopoiesis. }\end{array}$ & $\begin{array}{c}\text { Increased secretion by adipocytes and placental cells, } \\
\text { leading to a chronic inflammatory process and } \\
\text { insulin resistance }\end{array}$ \\
\hline SHBG & Glycoprotein that binds androgen and estrogen. & $\begin{array}{l}\text { Decrease SHBG levels associated with } \\
\text { hyperinsulinemia and GDM }\end{array}$ \\
\hline
\end{tabular}

GDM-gestational diabetes mellitus; PAPP-A—pregnancy-associated plasma protein A; IGF-1—insulin growth factor 1; PLGF-placental growth factor; TNF- $\alpha$ - tumor necrosis factor $\alpha$; CRP-C—reactive protein; IL-6interleukin 6; and SHBG—-sex hormone-binding globulin.

The "ideal GDM marker" would be simple to obtain, fast, inexpensive, and, most importantly, clinically useful, with a high positive predictive value. The optimal biomarker will predict GDM development before it occurs and therefore will allow for early intervention and improved outcomes for the short and long term, thus making it cost-effective.

\section{Predicting GDM by Early Glycemic Markers}

Overt diabetes can be diagnosed in the first trimester by using one of several glycemic measures: fasting glucose $\geq 126 \mathrm{mg} / \mathrm{dL}$, post-load glucose $\geq 200 \mathrm{mg} / \mathrm{dL}$, or hemoglobin $\mathrm{A} 1 \mathrm{c}(\mathrm{HbA} 1 \mathrm{c}) \geq 6.5 \%$, and is then considered as pregestational diabetes [37,38]. A number of studies have tried to assess whether these glycemic markers can be used in the first trimester to predict the risk for GDM development later in pregnancy.

\subsection{Fasting Glucose}

In 2010, the International Association of Diabetes and Pregnancy Study Group recommended different thresholds for diagnosis and classification of hyperglycemia in pregnancy based on the results of the HAPO study [39]. The panel recommended the use of firsttrimester fasting glucose above $92 \mathrm{mg} / \mathrm{dL}$ to diagnose early GDM; however, this approach was criticized due to a lack of evidence [38,40]. Although not established as a diagnostic marker, several studies have demonstrated an association between first-trimester fasting glucose and GDM development in late pregnancy. Mashiah et al. showed strong, graded associations between fasting glucose levels in the first trimester and GDM development, macrosomia, and cesarean section [41]. Other studies have shown that elevated firsttrimester fasting glucose levels have sensitivities of $47-75 \%$ and specificities of $52-77 \%$ for the prediction of GDM later in pregnancy [42,43], making the predictive value of fasting glucose similar to the risk factor of BMI [42]. Nevertheless, a definitive clinically useful cut-off for first-trimester fasting glucose has not been established and results show an insufficient predictive value for this marker.

\section{2. $\mathrm{HbA1c}$}

$\mathrm{HbA1c}$ is used to estimate average blood glucose over the lifespan of a red blood cell ( 120 days). HbA1c does not require fasting and is used in non-pregnant populations to 
diagnose and monitor both pre-diabetes and diabetes [44]. Several studies demonstrated that a first-trimester $\mathrm{HbA} 1 \mathrm{c}$ in the pre-diabetic values (5.7-6.4\%) is correlated with GDM manifestation in late pregnancy and associated with adverse pregnancy outcomes [45-47]. Although a significant risk factor for GDM, the low sensitivity of $\mathrm{HbA} 1 \mathrm{c}$ in this range makes it a poor test to identify women who will develop GDM [46]. HbA1c levels are also subjected to pregnancy changes and possibly require pregnancy-specific reference ranges [48]. Finally, Osmundson et al. conducted a randomized control trial which showed that treatment of women with early (before 14 weeks' gestation) pre-diabetic HbA1c (5.7-6.4\%) did not reduce the risk of GDM later in pregnancy, except in non-obese women [49]. In summary, current evidence does not support the use of $\mathrm{HbA} 1 \mathrm{c}$ as an effective early predictor for GDM.

\section{Predicting GDM by Adipokines}

Adipokines are cytokines that are produced by the adipose tissue and play a fundamental role in the development of metabolic morbidities, including diabetes. As such, a number of them were evaluated as biomarkers for GDM prediction [50,51]. Mainly, adiponectin and leptin were investigated, with evidence showing altered levels in GDM pregnancies. Others, including resistin [52], visfatin [53], and retinol-binding protein 4 [54], were inconsistently associated with GDM.

\subsection{Adiponectin}

Adiponectin is a protein secreted primarily by the adipose tissue but also by the brain, skeletal muscle, and placenta [55]. Adiponectin augments insulin sensitivity and low levels of adiponectin are associated with obesity, T2DM, hypertension, and coronary artery disease [56,57]. In normal pregnancy, maternal adiponectin secretion progressively declines probably due to decreased insulin sensitivity [58].

Previous studies have demonstrated that low levels of adiponectin in the first trimester are associated with GDM development later in pregnancy [53,59,60]. A metanalysis by Iliodromiti et al. suggested that early pregnancy adiponectin levels have a moderate predictive value for GDM, similar to that of clinical risk factors [61]. In summary, adiponectin may play a role in the pathophysiology of GDM and has the potential for a promising predictive biomarker. Further research is needed to further establish the true value of adiponectin in GDM prediction.

\subsection{Leptin}

Leptin regulates energy intake, suppresses appetite, and enhances the insulin effect with both central and peripheral effects [62]. Leptin is also expressed by placental cells and levels increase up to three-folds in pregnancy likely due to placental secretion and an increase in fat tissue; however, its exact role in pregnancy remains unclear $[63,64]$. Evidence regarding the association between leptin levels and GDM is inconsistent, with some studies demonstrating higher leptin levels in women who subsequently develop GDM [50,65], whereas others showed no difference $[66,67]$. Future prospective studies are required to determine leptin predictive ability in GDM while adequately addressing the confounding influence of BMI and gestational weight gain on leptin levels in pregnancy.

\section{Predicting GDM by Pregnancy-Related Proteins}

\subsection{Pregnancy-Associated Plasma Protein A (PAPP-A)}

PAPP-A is a metalloproteinase that increases the bioavailability of insulin-like growth factor 1 (IGF-1) by its cleavage from IGF binding protein-4 [68]. In pregnancy, PAPP-A is secreted by trophoblast cells and used as a first-trimester screening test for aneuploidy, as well as a predictor of placental disorders such as preeclampsia and fetal growth restriction [69]. It has been hypothesized that PAPP-A has a role in regulating glucose levels in pregnancy, with low levels associated with insulin resistance and GDM. 
Nonetheless, previous studies have yielded conflicting results. A number of studies reported low first-trimester PAPP-A levels in women who eventually developed GDM [70-73]. Additionally, a large systematic review and meta-analysis by Donovan et al. concluded that women who are diagnosed with GDM have lower first-trimester levels of PAPP-A, even though a high degree of between-study heterogeneity was noted [74]. Other studies failed to demonstrate differences in PAPP-A levels in pregnancies with GDM compared to normal pregnancies $[75,76]$ and Syngelaki et al. showed that the performance of screening for GDM by maternal factors was not improved by the addition of PAPP-A [77]. Future prospective studies are required to establish the clinical utility of this biomarker.

\subsection{Placental Growth Factor (PLGF)}

PLGF is an angiogenic protein highly expressed in the placenta [78]. PLGF is widely used in aneuploidy screening in the first trimester, with low levels associated with placentalmediated disorders, mainly preeclampsia and fetal growth restriction [79].

Several studies have shown that elevated PLGF levels in early pregnancy are associated with GDM development $[80,81]$. However, other studies have demonstrated no differences in PLGF levels between women who developed GDM and controls [82,83]. Additionally, a large prospective cohort study from the UK showed that even though early PLGF levels were higher in women with GDM, the addition of PLGF to a prediction model that includes maternal factors did not improve the predictive ability [77]. Therefore, current evidence does not support the use of PLGF as an effective biomarker for GDM.

\subsection{First-Trimester Combined Test (FTCT)}

The FTCT is an effective screening tool for fetal aneuploidy, which includes the combination of maternal age, ultrasound measurement of fetal nuchal translucency, and the serum markers-free $\beta$-human chorionic gonadotropin and PAPP-A. As an early, routinely implemented test, which includes pregnancy-related proteins, the FTCT has the potential to be used as a tool for the prediction of GDM. Visconti et al. showed that an FTCT result of $<1: 10,000$ was significantly associated with GDM development later in pregnancy, but with low accuracy [84], and other studies failed to demonstrate this association [76,85]. Based on current evidence, it is unclear whether the use of low PAPP-A solely (in absolute levels or in multiples of the median) contributes to GDM prediction better than the entire FTCT.

\section{Predicting GDM by Inflammatory Markers}

\subsection{Tumor Necrosis Factor- $\alpha$ (TNF- $\alpha)$}

TNF- $\alpha$ is an inflammatory cytokine that is produced by placental cells and has been suggested as a mediator for insulin resistance in pregnancy [86]. While some studies showed an association between elevated levels of TNF- $\alpha$ in the first trimester and GDM development later in pregnancy $[87,88]$, others failed to demonstrate this effect $[67,89]$. Furthermore, adding TNF- $\alpha$ to a screening model did not improve the prediction of GDM over maternal clinical characteristics [90]. In summary, even though TNF- $\alpha$ probably has a role in the pathogenesis of insulin resistance and GDM, the actual predictive value of this biomarker is yet to be established.

\subsection{C-Reactive Protein (CRP)}

CRP is an acute-phase protein secreted and released in response to tissue injury, inflammation, and infection [91]. Evidence regarding the association between levels of CRP or high-sensitivity CRP and GDM is inconsistent, with multiple studies showing high first-trimester levels in women who eventually develop GDM [92-95] and some studies not $[90,96]$. A possible confounder is the fact that CRP levels in pregnancy correlate with BMI and a prospective study by Wolf et al. concluded that the association between increased CRP and GDM was attenuated when BMI was included in the model [97]; the same effect was reported by others as well $[98,99]$. A recent systematic review by Amirian et al. 
discussed conflicting evidence and concluded that more studies are needed for CRP to be used as an indicator for GDM [100].

\subsection{Interleukin 6 (IL-6)}

IL-6 is a circulating inflammatory cytokine secreted by adipocytes as well as by macrophages, endothelial cells, pancreatic cells, and placenta cells [101]. IL-6 is involved in the regulation of immune response regulation, inflammation, and hematopoiesis [102], but also has a significant role in obesity and insulin resistance [103]. A systematic review and meta-analysis by Wang et al. concluded that IL-6 is a strong predictor of developing T2DM [104].

Previous studies showed an association between high levels of IL-6 and GDM [105-107]; however, these studies were limited by the gestational age at which IL-6 levels were measured, the population assessed, and by controlling for confounders such as BMI. Other studies failed to demonstrate a difference in IL-6 levels between GDM and normal pregnancies $[108,109]$. Nevertheless, a study by Hassiakos et al. showed that first-trimester IL-6 levels were a significant predictor of GDM development later in pregnancy and adding IL-6 to a prediction model that included maternal characteristics yielded an improved prediction [110]. A systematic review by Amirian et al. concluded that IL-6 levels are significantly higher in pregnant women with GDM than in healthy pregnant women and therefore the evaluation of this marker as a GDM predictor can be investigated [111]. In summary, although IL-6 has the potential to be a good biomarker for GDM in the future as demonstrated in T2DM, current evidence does not support it as such. Larger prospective studies are needed to assess IL-6 function in GDM as well as to adjust for obesity as a confounder and to obtain serial IL-6 measurements for the identification of trimester-specific ranges.

\section{Predicting GDM by Insulin Resistance Markers}

Several studies have suggested that GDM is associated with an increase in insulin resistance $[112,113]$ and therefore markers of insulin resistance were evaluated as potential biomarkers for GDM. Evaluation of first-trimester fasting insulin and the corresponding Homeostatic Model Assessment of Insulin Resistance as GDM predictors yielded limited predictive values $[114,115]$ and still require fasting. Sex hormone-binding globulin (SHBG) showed better results as a possible GDM predictor.

\section{SHBG}

SHBG is a glycoprotein produced mainly by the liver, binds androgen and estrogen, and has an inverse relationship with insulin levels [116]. Low levels of SHBG prior to pregnancy $[117,118]$ and in the first trimester $[92,119,120]$ were found to be correlated with GDM development later in pregnancy. Nanda et al. showed that adding SHBG to a clinical risk prediction model improved its accuracy [121]. However, in other studies this association was not found [122] or was no longer significant after adjusting for BMI, ethnicity, and family history [96]. Hence, even though SHBG is a very promising marker for early diagnosis of GDM, with even pre-pregnancy predictability, further studies are required to establish its role.

\section{Early Prediction to Improve Maternal, Placental and Fetal Dialog}

GDM is regarded as one of the "great obstetrical syndromes". The underlying concept hypothesizes that GDM has many underlying etiologies that adversely interact with the maternal-fetal unit and initiate subclinical pathology, which progresses to clinical manifestation that also results in fetal involvement [123].

According to this hypothesis, the placenta has a crucial role in the development of GDM and in mediating the metabolic effect on the fetus with a direct effect on pregnancy outcomes. Thus, for example, the placenta acts as a buffer of glucose levels for the fetus. Placental dysfunction will lead to over or under-transfer of glucose to the fetus. Moreover, 
the disruption of normal placental development is most profound if it occurs early in gestation, such as in pregestational diabetes. Considering early disruption of the placenta occurs at a time of structural evolution and vasculature development, major placental dysfunction leading to hypertensive disorders and abnormal fetal growth may ensue. Indeed, studies reveal that maternal diabetes is associated with histological changes in the placenta. Madazli et al. compared the histology of 22 placentas from women with well-controlled GDM to 22 placentas from non-diabetic women that served as a control and found a six-fold increase in villous immaturity and chorangiosis, as well as a three-fold increase in ischemic changes in the placentas of women diagnosed with GDM [124].

While pregestational diabetes is associated with marked structural changes in the placenta, subtle functional changes are more prevalent with later-onset GDM [125,126]. Although subtle, these changes are associated with increased intervillous diffuse distance, and may predispose the fetus to acute and chronic changes in gas as well as in other nutrients' exchange [125,126], thus making the fetus more vulnerable and turning the placenta from being protective to a potential source of adverse fetal outcome. Whether tight control of glucose levels abolishes the placental changes and pregnancy adverse outcomes is controversial. Jones et al. observed various degrees of changes in the syncytiotrophoblast, cytotrophoblast, trophoblastic basement membrane, and fetal vessels in diabetic women regardless of diabetic severity [127]. Moreover, Daskalakis et al. reported on an evaluation of a large number of placentas by a pathologist who was blinded to maternal glycemic status. The authors showed that GDM was associated with villous immaturity, chorangiosis, villous fibrinoid necrosis, and nucleated red blood cells regardless of maternal glycemic status [125].

First-trimester GDM biomarkers that originate in the placental tissue, such as PAPP-A and TNF- $\alpha$, support the hypothesis that the impaired placenta is an early mediator to adverse fetal outcomes. The prediction of abnormal glucose maternal-fetal metabolism at early pregnancy and quick intervention may prevent placental remodeling and ensure the protective nature of the placenta.

\section{Future Directions}

As individual first-trimester markers showed a modest predictive value for GDM, early pregnancy screening models combining biomarkers with demographic and clinical risk factors were evaluated $[32,90,110,121,128,129]$. Current evidence demonstrates minimal improvement of GDM prediction in combining models compared to prediction based on maternal risk factors and therefore the search for the optimal model is still ongoing.

In recent years, significant progress has been made in the field of metabolomics, which is the study of small-molecule metabolites in cells, tissues, and organisms. Metabolomic studies using mass spectrometry and nuclear magnetic resonance spectroscopy have already identified small-molecule metabolic products of lipids, carbohydrates, and amino acid metabolites, with suggested possible mechanisms in T2DM [130,131]. Using the same methods, metabolomics is a promising approach for investigating the metabolic pathways associated with the pathogenesis of GDM, as well as for detecting biomarkers of GDM, and future studies will assess their predictive value [132].

Epigenetic modifications-chromosomal changes that do not involve alterations in the DNA sequence-may have a role in GDM pathogenesis [133,134]. Animal models have demonstrated that maternal exposure to high-fat diets is associated with increased fetal epigenetic modifications associated with metabolic dysregulation [135,136]. More recent data in humans showed an association between maternal GDM and changes in DNA methylation of the offspring, measured in blood samples from the umbilical cord, the placenta, or peripheral blood [134,137-139]. Future research will focus on whether epigenetic changes, especially DNA methylation, occur before GDM development and if epigenetic signatures can be used as predictive markers of GDM [140]. 


\section{Conclusions}

Currently, GDM is usually diagnosed during the third trimester when unfavorable metabolic conditions might have already affected the fetus. Multiple biomarkers have been assessed as potential first-trimester predictors of GDM, including glycemic markers, adipokines, pregnancy-related proteins, inflammatory markers, and others. Most studies evaluating these markers were small retrospective studies that yielded limited results. As the prevalence of GDM continues to rise correspondingly with obesity rates worldwide, the need for an effective predictive biomarker for GDM is increasing. In order to translate current findings to a pragmatic clinical practice, future studies must not only find biomarkers predictive for GDM but must also assess their reproductivity in large multi-ethnic clinical trials and cost-effectiveness analyses. The identification and validation of such novel biomarkers has the potential to significantly improve the diagnosis and outcomes of GDM for mothers, newborns, and society as a whole.

Author Contributions: A.N., E.M.-S., M.H. and R.G.-B. contributed to writing this review. All authors have read and agreed to the published version of the manuscript.

Funding: This research received no external funding.

Conflicts of Interest: The authors declare no conflict of interest.

\section{References}

1. ACOG Practice Bulletin No. 190: Gestational Diabetes Mellitus. Obstet Gynecol. 2018, 131, e49-e64.

2. Zhu, Y.; Zhang, C. Prevalence of Gestational Diabetes and Risk of Progression to Type 2 Diabetes: A Global Perspective. Curr. Diabetes Rep. 2016, 16, 7. [CrossRef]

3. Goedegebure, E.A.R.; Koning, S.H.; Hoogenberg, K.; Korteweg, F.J.; Lutgers, H.L.; Diekman, M.J.M.; Stekkinger, E.; van den Berg, P.P.; Zwart, J.J. Pregnancy outcomes in women with gestational diabetes mellitus diagnosed according to the WHO-2013 and WHO-1999 diagnostic criteria: A multicentre retrospective cohort study. BMC Pregnancy Childbirth 2018, 18, 152. [CrossRef] [PubMed]

4. $\quad$ Langer, O.; Yogev, Y.; Most, O.; Xenakis, E.M.J. Gestational diabetes: The consequences of not treating. Am. J. Obstet. Gynecol. 2005, 192, 989-997. [CrossRef]

5. Fetita, L.-S.; Sobngwi, E.; Serradas, P.; Calvo, F.; Gautier, J.-F. Consequences of Fetal Exposure to Maternal Diabetes in Offspring. J. Clin. Endocrinol. Metab. 2006, 91, 3718-3724. [CrossRef]

6. Shah, B.R.; Retnakaran, R.; Booth, G.L. Increased risk of cardiovascular disease in young women following gestational diabetes mellitus. Diabetes Care 2008, 31, 1668-1669. [CrossRef]

7. Vandorsten, J.P.; Dodson, W.C.; Espeland, M.A.; Grobman, W.A.; Guise, J.M.; Mercer, B.M.; Minkoff, H.L.; Poindexter, B.; Prosser L.A.; Sawaya, G.F.; et al. NIH consensus development conference: Diagnosing gestational diabetes mellitus. NIH Consens. State Sci. Statements 2013, 29, 1-31. [PubMed]

8. Huhn, E.A.; Rossi, S.W.; Hoesli, I.; Göbl, C.S. Controversies in Screening and Diagnostic Criteria for Gestational Diabetes in Early and Late Pregnancy. Front. Endocrinol. 2018, 9, 696. [CrossRef]

9. Bogdanet, D.; O'Shea, P.; Lyons, C.; Shafat, A.; Dunne, F. The Oral Glucose Tolerance Test-Is It Time for a Change?-A Literature Review with an Emphasis on Pregnancy. J. Clin. Med. 2020, 9, 3451. [CrossRef]

10. Catalano, P.M. Carbohydrate metabolism and gestational diabetes. Clin. Obstet. Gynecol. 1994, 37, 25-38. [CrossRef]

11. Baz, B.; Riveline, J.-P.; Gautier, J.-F. Endocrinology of pregnancy: Gestational diabetes mellitus: Definition, aetiological and clinical aspects. Eur. J. Endocrinol. 2016, 174, R43-R51. [CrossRef]

12. Yogev, Y.; Xenakis, E.M.J.; Langer, O. The association between preeclampsia and the severity of gestational diabetes: The impact of glycemic control. Am. J. Obstet. Gynecol. 2004, 191, 1655-1660. [CrossRef] [PubMed]

13. Mahgoub, S.; Piant, H.; Gaudineau, A.; Lefebvre, F.; Langer, B.; Koch, A. Risk factors for obstetric anal sphincter injuries (OASIS) and the role of episiotomy: A retrospective series of 496 cases. J. Gynecol. Obstet. Hum. Reprod. 2019, 48, 657-662. [CrossRef] [PubMed]

14. Koivunen, S.; Viljakainen, M.; Männistö, T.; Gissler, M.; Pouta, A.; Kaaja, R.; Eriksson, J.; Laivuori, H.; Kajantie, E.; Vääräsmäki, M. Pregnancy outcomes according to the definition of gestational diabetes. PLoS ONE 2020, 15, e0229496. [CrossRef] [PubMed]

15. Metzger, B.E. Long-term Outcomes in Mothers Diagnosed with Gestational Diabetes Mellitus and Their Offspring. Clin. Obstet. Gynecol. 2007, 50, 972-979. [CrossRef] [PubMed]

16. Bellamy, L.; Casas, J.-P.; Hingorani, A.D.; Williams, D. Type 2 diabetes mellitus after gestational diabetes: A systematic review and meta-analysis. Lancet Lond. Engl. 2009, 373, 1773-1779. [CrossRef]

17. Mitanchez, D. Foetal and neonatal complications in gestational diabetes: Perinatal mortality, congenital malformations, macrosomia, shoulder dystocia, birth injuries, neonatal complications. Diabetes Metab. 2010, 36, 617-627. [CrossRef] [PubMed] 
18. Mitanchez, D.; Burguet, A.; Simeoni, U. Infants born to mothers with gestational diabetes mellitus: Mild neonatal effects, a long-term threat to global health. J. Pediatr. 2014, 164, 445-450. [CrossRef]

19. Hyperglycemia and Adverse Pregnancy Outcomes. N. Engl. J. Med. 2008, 358, 1991-2002. [CrossRef] [PubMed]

20. Kim, S.Y.; England, J.L.; Sharma, J.A.; Njoroge, T. Gestational diabetes mellitus and risk of childhood overweight and obesity in offspring: A systematic review. Exp. Diabetes Res. 2011, 2011, 541308. [CrossRef]

21. Roeckner, J.T.; Sanchez-Ramos, L.; Jijon-Knupp, R.; Kaunitz, A.M. Single abnormal value on 3-hour oral glucose tolerance test during pregnancy is associated with adverse maternal and neonatal outcomes: A systematic review and metaanalysis. Am. J. Obstet. Gynecol. 2016, 215, 287-297. [CrossRef] [PubMed]

22. Berezowsky, A.; Raban, O.; Aviram, A.; Zafrir-Danieli, H.; Krispin, E.; Hadar, E. Glucose tolerance test with a single abnormal value in pregnancy and the risk of type-2 diabetes mellitus. Arch. Gynecol. Obstet. 2021. [CrossRef] [PubMed]

23. Crowther, C.A.; Hiller, J.E.; Moss, J.R.; McPhee, A.J.; Jeffries, W.S.; Robinson, J.S. Effect of Treatment of Gestational Diabetes Mellitus on Pregnancy Outcomes. N. Engl. J. Med. 2005, 352, 2477-2486. [CrossRef] [PubMed]

24. Landon, M.B.; Spong, C.Y.; Thom, E.; Carpenter, M.W.; Ramin, S.M.; Casey, B.; Wapner, R.J.; Varner, M.W.; Rouse, D.J.; Thorp, J.M.; et al. A Multicenter, Randomized Trial of Treatment for Mild Gestational Diabetes. N. Engl. J. Med. 2009, 361, 1339-1348. [CrossRef] [PubMed]

25. Mirabelli, M.; Chiefari, E.; Tocci, V.; Greco, E.; Foti, D.; Brunetti, A. Gestational diabetes: Implications for fetal growth, intervention timing, and treatment options. Curr. Opin. Pharmacol. 2021, 60, 1-10. [CrossRef]

26. Farrar, D.; Simmonds, M.; Bryant, M.; Lawlor, D.A.; Dunne, F.; Tuffnell, D.; Sheldon, T.A. Risk factor screening to identify women requiring oral glucose tolerance testing to diagnose gestational diabetes: A systematic review and meta-analysis and analysis of two pregnancy cohorts. PLoS ONE 2017, 12, e0175288. [CrossRef]

27. Li, Y.; Ren, X.; He, L.; Li, J.; Zhang, S.; Chen, W. Maternal age and the risk of gestational diabetes mellitus: A systematic review and meta-analysis of over 120 million participants. Diabetes Res. Clin. Pract. 2020, 162, 108044. [CrossRef]

28. Chu, S.Y.; Callaghan, W.M.; Kim, S.Y.; Schmid, C.H.; Lau, J.; England, L.J.; Dietz, P.M. Maternal obesity and risk of gestational diabetes mellitus. Diabetes Care 2007, 30, 2070-2076. [CrossRef]

29. Roos, N.; Kieler, H.; Sahlin, L.; Ekman-Ordeberg, G.; Falconer, H.; Stephansson, O. Risk of adverse pregnancy outcomes in women with polycystic ovary syndrome: Population based cohort study. BMJ 2011, 343, d6309. [CrossRef]

30. Hiersch, L.; Berger, H.; Okby, R.; Ray, J.G.; Geary, M.; Mcdonald, S.D.; Murry-Davis, B.; Riddell, C.; Halperin, I.; Hasan, H.; et al Incidence and risk factors for gestational diabetes mellitus in twin versus singleton pregnancies. Arch. Gynecol. Obstet. 2018, 298, 579-587. [CrossRef]

31. Wang, Y.A.; Nikravan, R.; Smith, H.C.; Sullivan, E.A. Higher prevalence of gestational diabetes mellitus following assisted reproduction technology treatment. Hum. Reprod. Oxf. Engl. 2013, 28, 2554-2561. [CrossRef]

32. Syngelaki, A.; Pastides, A.; Kotecha, R.; Wright, A.; Akolekar, R.; Nicolaides, K.H. First-Trimester Screening for Gestational Diabetes Mellitus Based on Maternal Characteristics and History. Fetal. Diagn. Ther. 2015, 38, 14-21. [CrossRef] [PubMed]

33. Gabbay-Benziv, R.; Doyle, L.E.; Blitzer, M.; Baschat, A.A. First trimester prediction of maternal glycemic status. J. Perinat. Med. 2015, 43, 283-289. [CrossRef] [PubMed]

34. Diabetes in Pregnancy: Management of Diabetes and Its Complications from Pre-Conception to the Postnatal Period I Guidance I NICE [Internet]. NICE. Available online: https:/ /www.nice.org.uk/guidance/CG63 (accessed on 19 October 2021).

35. Coustan, D.R.; Nelson, C.; Carpenter, M.W.; Carr, S.R.; Rotondo, L.; Widness, J.A. Maternal age and screening for gestational diabetes: A population-based study. Obstet. Gynecol. 1989, 73, 557-561. [PubMed]

36. Bogdanet, D.; Reddin, C.; Murphy, D.; Doheny, H.C.; Halperin, J.A.; Dunne, F.; O'Shea, P. Emerging Protein Biomarkers for the Diagnosis or Prediction of Gestational Diabetes-A Scoping Review. J. Clin. Med. 2021, 10, 1533. [CrossRef]

37. American College of Obstetricians and Gynecologists' Committee on Practice Bulletins-Obstetrics. ACOG Practice Bulletin No. 201: Pregestational Diabetes Mellitus. Obstet. Gynecol. 2018, 132, e228-e248. [CrossRef]

38. American Diabetes Association. Classification and Diagnosis of Diabetes: Standards of Medical Care in Diabetes-2018. Diabetes Care 2018, 41, S13-S27. [CrossRef]

39. International Association of Diabetes and Pregnancy Study Groups Consensus Panel; Metzger, B.E.; Gabbe, S.G.; Persson, B.; Buchanan, T.A.; Catalano, P.A.; Damm, P.; Dyer, A.R.; de Leiva, A.; Hod, M.; et al. International association of diabetes and pregnancy study groups recommendations on the diagnosis and classification of hyperglycemia in pregnancy. Diabetes Care 2010, 33, 676-682. [CrossRef]

40. Hillier, T.A.; Pedula, K.L.; Ogasawara, K.K.; Vesco, K.K.; Oshiro, C.E.S.; Lubarsky, S.L.; Van Marter, J. A Pragmatic, Randomized Clinical Trial of Gestational Diabetes Screening. N. Engl. J. Med. 2021, 384, 895-904. [CrossRef]

41. Riskin-Mashiah, S.; Younes, G.; Damti, A.; Auslender, R. First-trimester fasting hyperglycemia and adverse pregnancy outcomes. Diabetes Care 2009, 32, 1639-1643. [CrossRef]

42. Riskin-Mashiah, S.; Damti, A.; Younes, G.; Auslender, R. First trimester fasting hyperglycemia as a predictor for the development of gestational diabetes mellitus. Eur. J. Obstet. Gynecol. Reprod. Biol. 2010, 152, 163-167. [CrossRef] [PubMed]

43. Yeral, M.I.; Ozgu-Erdinc, A.S.; Uygur, D.; Seckin, K.D.; Karsli, M.F.; Danisman, A.N. Prediction of gestational diabetes mellitus in the first trimester, comparison of fasting plasma glucose, two-step and one-step methods: A prospective randomized controlled trial. Endocrine 2014, 46, 512-518. [CrossRef] [PubMed] 
44. American Diabetes Association. Standards of Medical Care in Diabetes-2016: Summary of Revisions. Diabetes Care 2016, 39 (Suppl. 1), S4-S5. [CrossRef] [PubMed]

45. Fong, A.; Serra, A.E.; Gabby, L.; Wing, D.A.; Berkowitz, K.M. Use of hemoglobin A1c as an early predictor of gestational diabetes mellitus. Am. J. Obstet. Gynecol. 2014, 211, 641.e1-641.e7. [CrossRef]

46. Osmundson, S.S.; Zhao, B.S.; Kunz, L.; Wang, E.; Popat, R.; Nimbal, V.C.; Palaniappan, L.P. First Trimester Hemoglobin A1c Prediction of Gestational Diabetes. Am. J. Perinatol. 2016, 33, 977-982. [CrossRef]

47. Hughes, R.C.E.; Moore, M.P.; Gullam, J.E.; Mohamed, K.; Rowan, J. An early pregnancy HbA1c $\geq 5.9 \%$ ( $41 \mathrm{mmol} / \mathrm{mol})$ is optimal for detecting diabetes and identifies women at increased risk of adverse pregnancy outcomes. Diabetes Care 2014, 37, $2953-2959$. [CrossRef]

48. Hughes, R.C.E.; Rowan, J.; Florkowski, C.M. Is There a Role for HbA1c in Pregnancy? Curr. Diabetes Rep. 2016, 16, 5. [CrossRef]

49. Osmundson, S.S.; Norton, M.E.; El-Sayed, Y.Y.; Carter, S.; Faig, J.C.; Kitzmiller, J.L. Early Screening and Treatment of Women with Prediabetes: A Randomized Controlled Trial. Am. J. Perinatol. 2016, 33, 172-179.

50. Bao, W.; Baecker, A.; Song, Y.; Kiely, M.; Liu, S.; Zhang, C. Adipokine levels during the first or early second trimester of pregnancy and subsequent risk of gestational diabetes mellitus: A systematic review. Metabolism 2015, 64, 756-764. [CrossRef]

51. Fasshauer, M.; Blüher, M.; Stumvoll, M. Adipokines in gestational diabetes. Lancet Diabetes Endocrinol. 2014, 2, 488-499. [CrossRef]

52. Nanda, S.; Poon, L.C.Y.; Muhaisen, M.; Acosta, I.C.; Nicolaides, K.H. Maternal serum resistin at 11 to 13 weeks' gestation in normal and pathological pregnancies. Metabolism 2012, 61, 699-705. [CrossRef] [PubMed]

53. Ferreira, A.F.A.; Rezende, J.C.; Vaikousi, E.; Akolekar, R.; Nicolaides, K.H. Maternal serum visfatin at 11-13 weeks of gestation in gestational diabetes mellitus. Clin. Chem. 2011, 57, 609-613. [CrossRef]

54. Hu, S.; Liu, Q.; Huang, X.; Tan, H. Serum level and polymorphisms of retinol-binding protein-4 and risk for gestational diabetes mellitus: A meta-analysis. BMC Pregnancy Childbirth 2016, 16, 52. [CrossRef] [PubMed]

55. Chen, J.; Tan, B.; Karteris, E.; Zervou, S.; Digby, J.; Hillhouse, E.W.; Vatish, M.; Randeva, H.S. Secretion of adiponectin by human placenta: Differential modulation of adiponectin and its receptors by cytokines. Diabetologia 2006, 49, 1292-1302. [CrossRef] [PubMed]

56. Chandran, M.; Phillips, S.A.; Ciaraldi, T.; Henry, R.R. Adiponectin: More than just another fat cell hormone? Diabetes Care 2003, 26, 2442-2450. [CrossRef] [PubMed]

57. Weyer, C.; Funahashi, T.; Tanaka, S.; Hotta, K.; Matsuzawa, Y.; Pratley, R.E.; Tataranni, P. Hypoadiponectinemia in obesity and type 2 diabetes: Close association with insulin resistance and hyperinsulinemia. J. Clin. Endocrinol. Metab. 2001, 86, 1930-1935. [CrossRef]

58. Galic, S.; Oakhill, J.S.; Steinberg, G.R. Adipose tissue as an endocrine organ. Mol. Cell. Endocrinol. 2010, 316, 129-139. [CrossRef]

59. Lain, K.Y.; Daftary, A.R.; Ness, R.B.; Roberts, J.M. First trimester adipocytokine concentrations and risk of developing gestational diabetes later in pregnancy. Clin. Endocrinol. 2008, 69, 407-411. [CrossRef]

60. Lacroix, M.; Battista, M.-C.; Doyon, M.; Ménard, J.; Ardilouze, J.-L.; Perron, P.; Hivert, M.-F. Lower adiponectin levels at first trimester of pregnancy are associated with increased insulin resistance and higher risk of developing gestational diabetes mellitus. Diabetes Care 2013, 36, 1577-1583. [CrossRef]

61. Iliodromiti, S.; Sassarini, J.; Kelsey, T.W.; Lindsay, R.S.; Sattar, N.; Nelson, S.M. Accuracy of circulating adiponectin for predicting gestational diabetes: A systematic review and meta-analysis. Diabetologia 2016, 59, 692-699. [CrossRef]

62. Triantafyllou, G.A.; Paschou, S.A.; Mantzoros, C.S. Leptin and Hormones: Energy Homeostasis. Endocrinol. Metab. Clin. N. Am. 2016, 45, 633-645. [CrossRef] [PubMed]

63. Fattah, C.; Barry, S.; O'connor, N.; Farah, N.; Stuart, B.; Turner, M.J. Maternal leptin and body composition in the first trimester of pregnancy. Gynecol. Endocrinol. Off. J. Int. Soc. Gynecol. Endocrinol. 2011, 27, 263-266. [CrossRef] [PubMed]

64. Briana, D.D.; Malamitsi-Puchner, A. Reviews: Adipocytokines in normal and complicated pregnancies. Reprod. Sci. Thousand Oaks Calif. 2009, 16, 921-937. [CrossRef] [PubMed]

65. Sommer, C.; Jenum, A.K.; Waage, C.W.; Mørkrid, K.; Sletner, L.; Birkeland, K.I. Ethnic differences in BMI, subcutaneous fat, and serum leptin levels during and after pregnancy and risk of gestational diabetes. Eur. J. Endocrinol. 2015, 172, 649-656. [CrossRef]

66. Maple-Brown, L.; Ye, C.; Hanley, A.J.; Connelly, P.W.; Sermer, M.; Zinman, B.; Retnakaran, R. Maternal pregravid weight is the primary determinant of serum leptin and its metabolic associations in pregnancy, irrespective of gestational glucose tolerance status. J. Clin. Endocrinol. Metab. 2012, 97, 4148-4155. [CrossRef]

67. Georgiou, H.M.; Lappas, M.; Georgiou, G.M.; Marita, A.; Bryant, V.J.; Hiscock, R.; Permezel, M.; Khalil, Z.; Rice, G.E. Screening for biomarkers predictive of gestational diabetes mellitus. Acta Diabetol. 2008, 45, 157-165. [CrossRef]

68. Boldt, H.B.; Conover, C.A. Pregnancy-associated plasma protein-A (PAPP-A): A local regulator of IGF bioavailability through cleavage of IGFBPs. Growth Horm. IGF Res. 2007, 17, 10-18. [CrossRef]

69. Dugoff, L.; Hobbins, J.C.; Malone, F.D.; Porter, T.F.; Luthy, D.; Comstock, C.H.; Hankins, G.; Berkowitz, R.L.; Merkatz, I.; Craigo, S.D.; et al. First-trimester maternal serum PAPP-A and free-beta subunit human chorionic gonadotropin concentrations and nuchal translucency are associated with obstetric complications: A population-based screening study (the FASTER Trial). Am. J. Obstet. Gynecol. 2004, 191, 1446-1451. [CrossRef]

70. Ren, Z.; Zhe, D.; Li, Z.; Sun, X.-P.; Yang, K.; Lin, L. Study on the correlation and predictive value of serum pregnancy-associated plasma protein A, triglyceride and serum 25-hydroxyvitamin D levels with gestational diabetes mellitus. World J. Clin. Cases 2020, 8, 864-873. [CrossRef] 
71. Beneventi, F.; Simonetta, M.; Lovati, E.; Albonico, G.; Tinelli, C.; Locatelli, E.; Spinillo, A. First trimester pregnancy-associated plasma protein-A in pregnancies complicated by subsequent gestational diabetes. Prenat. Diagn. 2011, 31, 523-528. [CrossRef]

72. Ramezani, S.; Doulabi, M.A.; Saqhafi, H.; Alipoor, M. Prediction of Gestational Diabetes by Measuring the Levels of Pregnancy Associated Plasma Protein-A (PAPP-A) During Gestation Weeks 11-14. J. Reprod. Infertil. 2020, 21, 130-137. [PubMed]

73. Wells, G.; Bleicher, K.; Han, X.; McShane, M.; Chan, Y.F.; Bartlett, A.; White, C.; Lau, S.M. Maternal Diabetes, Large-for-GestationalAge Births, and First Trimester Pregnancy-Associated Plasma Protein-A. J. Clin. Endocrinol. Metab. 2015, 100, $2372-2379$. [CrossRef] [PubMed]

74. Donovan, B.M.; Nidey, N.L.; Jasper, E.A.; Robinson, J.G.; Bao, W.; Saftlas, A.F.; Ryckman, K.K. First trimester prenatal screening biomarkers and gestational diabetes mellitus: A systematic review and meta-analysis. PLoS ONE 2018, 13, e0201319. [CrossRef] [PubMed]

75. Husslein, H.; Lausegger, F.; Leipold, H.; Worda, C. Association between pregnancy-associated plasma protein-A and gestational diabetes requiring insulin treatment at 11-14 weeks of gestation. J. Matern.-Fetal Neonatal Med. 2012, 25, 2230-2233. [CrossRef] [PubMed]

76. Savvidou, M.D.; Syngelaki, A.; Muhaisen, M.; Emelyanenko, E.; Nicolaides, K.H. First trimester maternal serum free $\beta$-human chorionic gonadotropin and pregnancy-associated plasma protein A in pregnancies complicated by diabetes mellitus. BJOG Int. J. Obstet. Gynaecol. 2012, 119, 410-416. [CrossRef]

77. Syngelaki, A.; Kotecha, R.; Pastides, A.; Wright, A.; Nicolaides, K.H. First-trimester biochemical markers of placentation in screening for gestational diabetes mellitus. Metabolism 2015, 64, 1485-1489. [CrossRef]

78. Chau, K.; Hennessy, A.; Makris, A. Placental growth factor and pre-eclampsia. J. Hum. Hypertens. 2017, 31, 782-786. [CrossRef]

79. O'Gorman, N.; Wright, D.; Syngelaki, A.; Akolekar, R.; Wright, A.; Poon, L.C.; Nicolaides, K.H. Competing risks model in screening for preeclampsia by maternal factors and biomarkers at 11-13 weeks gestation. Am. J. Obstet. Gynecol. 2016, 214, 103.e1-103.e12. [CrossRef]

80. Eleftheriades, M.; Papastefanou, I.; Lambrinoudaki, I.; Kappou, D.; Lavranos, D.; Akalestos, A.; Souka, A.P.; Pervanidou, P.; Hassiakos, D.; Chrousos, G.P. Elevated placental growth factor concentrations at 11-14 weeks of gestation to predict gestational diabetes mellitus. Metabolism 2014, 63, 1419-1425. [CrossRef]

81. Gorkem, U.; Togrul, C.; Arslan, E. Relationship between elevated serum level of placental growth factor and status of gestational diabetes mellitus. J. Matern.-Fetal Neonatal Med. 2020, 33, 4159-4163. [CrossRef]

82. Mosimann, B.; Amylidi, S.; Risch, L.; Wiedemann, U.; Surbek, D.; Baumann, M.; Stettler, C.; Raio, L. First-Trimester Placental Growth Factor in Screening for Gestational Diabetes. Fetal Diagn. Ther. 2016, 39, 287-291. [CrossRef] [PubMed]

83. Maymon, R.; Meiri, H.; Svirski, R.; Weiner, E.; Cuckle, H. Maternal serum screening marker levels in twin pregnancies affected by gestational diabetes. Arch. Gynecol. Obstet. 2019, 299, 655-663. [CrossRef]

84. Visconti, F.; Quaresima, P.; Chiefari, E.; Caroleo, P.; Arcidiacono, B.; Puccio, L.; Mirabelli, M.; Foti, D.P.; Di Carlo, C.; Vero, R.; et al. First Trimester Combined Test (FTCT) as a Predictor of Gestational Diabetes Mellitus. Int. J. Environ. Res. Public Health 2019, 16, 3654. [CrossRef] [PubMed]

85. Tul, N.; Pusenjak, S.; Osredkar, J.; Spencer, K.; Novak-Antolic, Z. Predicting complications of pregnancy with first-trimester maternal serum free-betahCG, PAPP-A and inhibin-A. Prenat. Diagn. 2003, 23, 990-996. [CrossRef] [PubMed]

86. Desoye, G.; Hauguel-de Mouzon, S. The human placenta in gestational diabetes mellitus. The insulin and cytokine network. Diabetes Care 2007, 30 (Suppl. 2), S120-S126. [CrossRef] [PubMed]

87. Xu, J.; Zhao, Y.H.; Chen, Y.P.; Yuan, X.L.; Wang, J.; Zhu, H.; Lu, C.M. Maternal circulating concentrations of tumor necrosis factor-alpha, leptin, and adiponectin in gestational diabetes mellitus: A systematic review and meta-analysis. Sci. World J. 2014, 2014, 926932. [CrossRef]

88. Gao, X.; Yang, H.; Zhao, Y. Variations of tumor necrosis factor-alpha, leptin and adiponectin in mid-trimester of gestational diabetes mellitus. Chin. Med. J. 2008, 121, 701-705. [CrossRef]

89. Guillemette, L.; Lacroix, M.; Battista, M.-C.; Doyon, M.; Moreau, J.; Ménard, J.; Ardilouze, J.-L.; Perron, P.; Hivert, M.-F. TNF $\alpha$ dynamics during the oral glucose tolerance test vary according to the level of insulin resistance in pregnant women. J. Clin. Endocrinol. Metab. 2014, 99, 1862-1869. [CrossRef]

90. Syngelaki, A.; Visser, G.H.A.; Krithinakis, K.; Wright, A.; Nicolaides, K.H. First trimester screening for gestational diabetes mellitus by maternal factors and markers of inflammation. Metabolism 2016, 65, 131-137. [CrossRef]

91. Sproston, N.R.; Ashworth, J.J. Role of C-Reactive Protein at Sites of Inflammation and Infection. Front Immunol. 2018, 9, 754. [CrossRef]

92. Maged, A.M.; Moety, G.A.F.; Mostafa, W.A.; Hamed, D.A. Comparative study between different biomarkers for early prediction of gestational diabetes mellitus. J. Matern.-Fetal Neonatal Med. 2014, 27, 1108-1112. [CrossRef]

93. Ozgu-Erdinc, A.S.; Yilmaz, S.; Yeral, M.I.; Seckin, K.D.; Erkaya, S.; Danisman, A.N. Prediction of gestational diabetes mellitus in the first trimester: Comparison of C-reactive protein, fasting plasma glucose, insulin and insulin sensitivity indices. J. Matern.-Fetal Neonatal Med. 2015, 28, 1957-1962. [CrossRef]

94. Alamolhoda, S.H.; Yazdkhasti, M.; Namdari, M.; Zakariayi, S.J.; Mirabi, P. Association between C-reactive protein and gestational diabetes: A prospective study. J. Obstet. Gynaecol. 2020, 40, 349-353. [CrossRef] [PubMed]

95. Alyas, S.; Roohi, N.; Ashraf, S.; Ilyas, S.; Ilyas, A. Early pregnancy biochemical markers of placentation for screening of gestational diabetes mellitus (GDM). Diabetes Metab. Syndr. 2019, 13, 2353-2356. [CrossRef] [PubMed] 
96. Corcoran, S.M.; Achamallah, N.; Loughlin, J.O.; Stafford, P.; Dicker, P.; Malone, F.D.; Breathnach, F. First trimester serum biomarkers to predict gestational diabetes in a high-risk cohort: Striving for clinically useful thresholds. Eur. J. Obstet. Gynecol. Reprod. Biol. 2018, 222, 7-12. [CrossRef] [PubMed]

97. Wolf, M.; Sandler, L.; Hsu, K.; Vossen-Smirnakis, K.; Ecker, J.L.; Thadhani, R. First-trimester C-reactive protein and subsequent gestational diabetes. Diabetes Care 2003, 26, 819-824. [CrossRef]

98. Retnakaran, R.; Hanley, A.J.G.; Raif, N.; Connelly, P.W.; Sermer, M.; Zinman, B. C-reactive protein and gestational diabetes: The central role of maternal obesity. J. Clin. Endocrinol. Metab. 2003, 88, 3507-3512. [CrossRef]

99. Berggren, E.K.; Roeder, H.A.; Boggess, K.A.; Moss, K.; Offenbacher, S.; Campbell, E.; Grotegut, C.A. First-trimester maternal serum C-reactive protein as a predictor of third-trimester impaired glucose tolerance. Reprod. Sci. Thousand Oaks Calif. 2015, 22, 90-93. [CrossRef]

100. Amirian, A.; Rahnemaei, F.A.; Abdi, F. Role of C-reactive Protein(CRP) or high-sensitivity CRP in predicting gestational diabetes Mellitus: Systematic review. Diabetes Metab. Syndr. 2020, 14, 229-236. [CrossRef]

101. Van Snick, J. Interleukin-6: An overview. Annu. Rev. Immunol. 1990, 8, 253-278. [CrossRef]

102. Jordan, S.C.; Choi, J.; Kim, I.; Wu, G.; Toyoda, M.; Shin, B.; Vo, A. Interleukin-6, A Cytokine Critical to Mediation of Inflammation, Autoimmunity and Allograft Rejection: Therapeutic Implications of IL-6 Receptor Blockade. Transplantation 2017, 101, 32-44. [CrossRef] [PubMed]

103. Hoene, M.; Weigert, C. The role of interleukin-6 in insulin resistance, body fat distribution and energy balance. Obes. Rev. Off. J. Int. Assoc. Study Obes. 2008, 9, 20-29. [CrossRef]

104. Wang, X.; Bao, W.; Liu, J.; Ouyang, Y.-Y.; Wang, D.; Rong, S.; Xiao, X.; Shan, Z.-L.; Zhang, Y.; Yao, P.; et al. Inflammatory markers and risk of type 2 diabetes: A systematic review and meta-analysis. Diabetes Care 2013, 36, 166-175. [CrossRef]

105. Morisset, A.-S.; Dubé, M.-C.; Côté, J.A.; Robitaille, J.; Weisnagel, S.J.; Tchernof, A. Circulating interleukin-6 concentrations during and after gestational diabetes mellitus. Acta Obstet. Gynecol. Scand. 2011, 90, 524-530. [CrossRef]

106. Siddiqui, S.; Waghdhare, S.; Goel, C.; Panda, M.; Soneja, H.; Sundar, J.; Banerjee, M.; Jha, S.; Dubey, S. Augmentation of IL-6 production contributes to development of gestational diabetes mellitus: An Indian study. Diabetes Metab. Syndr. 2019, 13, 895-899. [CrossRef] [PubMed]

107. Abell, S.K.; Shorakae, S.; Harrison, C.L.; Hiam, D.; Moreno-Asso, A.; Stepto, N.K.; De Courten, B.; Teede, H.J. The association between dysregulated adipocytokines in early pregnancy and development of gestational diabetes. Diabetes Metab. Res. Rev. 2017, 33, e2926. [CrossRef] [PubMed]

108. Braga, F.O.; Negrato, C.A.; Matta, M.D.F.B.D.; Carneiro, J.R.I.; Gomes, M.B. Relationship between inflammatory markers, glycated hemoglobin and placental weight on fetal outcomes in women with gestational diabetes. Arch. Endocrinol. Metab. 2019, 63, 22-29. [CrossRef] [PubMed]

109. Šimják, P.; Cinkajzlová, A.; Anderlová, K.; Kloučková, J.; Kratochvílová, H.; Lacinová, Z.; Kaválková, P.; Krejčí, H.; Mráz, M.; Pařízek, A.; et al. Changes in plasma concentrations and mRNA expression of hepatokines fetuin A, fetuin B and FGF21 in physiological pregnancy and gestational diabetes mellitus. Physiol. Res. 2018, 67, S531-S542. [CrossRef] [PubMed]

110. Hassiakos, D.; Eleftheriades, M.; Papastefanou, I.; Lambrinoudaki, I.; Kappou, D.; Lavranos, D.; Akalestos, A.; Aravantinos, L.; Pervanidou, P.; Chrousos, G. Increased Maternal Serum Interleukin-6 Concentrations at 11 to 14 Weeks of Gestation in Low Risk Pregnancies Complicated with Gestational Diabetes Mellitus: Development of a Prediction Model. Horm. Metab. Res. Horm. Stoffwechs. Horm. Metab. 2016, 48, 35-41. [CrossRef] [PubMed]

111. Amirian, A.; Mahani, M.B.; Abdi, F. Role of interleukin-6 (IL-6) in predicting gestational diabetes mellitus. Obstet. Gynecol. Sci. 2020, 63, 407-416. [CrossRef]

112. Powe, C.E.; Allard, C.; Battista, M.-C.; Doyon, M.; Bouchard, L.; Ecker, J.L.; Perron, P.; Florez, J.C.; Thadhani, R.; Hivert, M.-F. Heterogeneous Contribution of Insulin Sensitivity and Secretion Defects to Gestational Diabetes Mellitus. Diabetes Care 2016, 39, 1052-1055. [CrossRef] [PubMed]

113. Smirnakis, K.V.; Martinez, A.; Blatman, K.H.; Wolf, M.; Ecker, J.L.; Thadhani, R. Early pregnancy insulin resistance and subsequent gestational diabetes mellitus. Diabetes Care 2005, 28, 1207-1208. [CrossRef] [PubMed]

114. Grewal, E.; Kansara, S.; Kachhawa, G.; Ammini, A.C.; Kriplani, A.; Aggarwal, N.; Gupta, N.; Khadgawat, R. Prediction of gestational diabetes mellitus at 24 to 28 weeks of gestation by using first-trimester insulin sensitivity indices in Asian Indian subjects. Metabolism 2012, 61, 715-720. [CrossRef] [PubMed]

115. Bitó, T.; Földesi, I.; Nyári, T.; Pál, A. Prediction of gestational diabetes mellitus in a high-risk group by insulin measurement in early pregnancy. Diabet. Med. J. Br. Diabet. Assoc. 2005, 22, 1434-1439. [CrossRef] [PubMed]

116. Wallace, I.R.; McKinley, M.C.; Bell, P.M.; Hunter, S.J. Sex hormone binding globulin and insulin resistance. Clin. Endocrinol. 2013, 78, 321-329. [CrossRef] [PubMed]

117. Hedderson, M.M.; Xu, F.; Darbinian, J.A.; Quesenberry, C.P.; Sridhar, S.; Kim, C.; Gunderson, E.P.; Ferrara, A. Prepregnancy SHBG concentrations and risk for subsequently developing gestational diabetes mellitus. Diabetes Care 2014, 37, 1296-1303. [CrossRef]

118. Veltman-Verhulst, S.M.; van Haeften, T.W.; Eijkemans, M.J.C.; de Valk, H.W.; Fauser, B.C.J.M.; Goverde, A.J. Sex hormone-binding globulin concentrations before conception as a predictor for gestational diabetes in women with polycystic ovary syndrome. Hum. Reprod. Oxf. Engl. 2010, 25, 3123-3128. [CrossRef] [PubMed]

119. Caglar, G.S.; Ozdemir, E.D.U.; Cengiz, S.D.; Demirtaş, S. Sex-hormone-binding globulin early in pregnancy for the prediction of severe gestational diabetes mellitus and related complications. J. Obstet. Gynaecol. Res. 2012, 38, 1286-1293. [CrossRef] 
120. Smirnakis, K.V.; Plati, A.; Wolf, M.; Thadhani, R.; Ecker, J.L. Predicting gestational diabetes: Choosing the optimal early serum marker. Am. J. Obstet. Gynecol. 2007, 196, 410.e1-6. [CrossRef]

121. Nanda, S.; Savvidou, M.; Syngelaki, A.; Akolekar, R.; Nicolaides, K.H. Prediction of gestational diabetes mellitus by maternal factors and biomarkers at 11 to 13 weeks. Prenat. Diagn. 2011, 31, 135-141. [CrossRef]

122. McElduff, A.; Hitchman, R.; McElduff, P. Is sex hormone-binding globulin associated with glucose tolerance? Diabet. Med. J. Br. Diabet. Assoc. 2006, 23, 306-312. [CrossRef] [PubMed]

123. Gabbay-Benziv, R.; Baschat, A.A. Gestational diabetes as one of the "great obstetrical syndromes" - The maternal, placental, and fetal dialog. Best Pract. Res. Clin. Obstet. Gynaecol. 2015, 29, 150-155. [CrossRef] [PubMed]

124. Madazli, R.; Tuten, A.; Calay, Z.; Uzun, H.; Uludag, S.; Ocak, V. The incidence of placental abnormalities, maternal and cord plasma malondialdehyde and vascular endothelial growth factor levels in women with gestational diabetes mellitus and nondiabetic controls. Gynecol. Obstet. Investig. 2008, 65, 227-232. [CrossRef]

125. Daskalakis, G.; Marinopoulos, S.; Krielesi, V.; Papapanagiotou, A.; Papantoniou, N.; Mesogitis, S.; Antsaklis, A. Placental pathology in women with gestational diabetes. Acta Obstet. Gynecol. Scand. 2008, 87, 403-407. [CrossRef] [PubMed]

126. Gauster, M.; Desoye, G.; Tötsch, M.; Hiden, U. The placenta and gestational diabetes mellitus. Curr. Diab. Rep. 2012, 12, 16-23. [CrossRef]

127. Jones, C.J.; Fox, H. Placental changes in gestational diabetes. An ultrastructural study. Obstet. Gynecol. 1976, 48, $274-280$.

128. Ravnsborg, T.; Andersen, L.L.T.; Trabjerg, N.D.; Rasmussen, L.M.; Jensen, D.M.; Overgaard, M. First-trimester multimarker prediction of gestational diabetes mellitus using targeted mass spectrometry. Diabetologia 2016, 59, 970-979. [CrossRef]

129. Thériault, S.; Giguère, Y.; Massé, J.; Girouard, J.; Forest, J.-C. Early prediction of gestational diabetes: A practical model combining clinical and biochemical markers. Clin. Chem. Lab. Med. 2016, 54, 509-518. [CrossRef] [PubMed]

130. Guasch-Ferré, M.; Hruby, A.; Toledo, E.; Clish, C.B.; Martínez-González, M.A.; Salas-Salvadó, J.; Hu, F.B. Metabolomics in Prediabetes and Diabetes: A Systematic Review and Meta-analysis. Diabetes Care 2016, 39, 833-846. [CrossRef]

131. Floegel, A.; Stefan, N.; Yu, Z.; Mühlenbruch, K.; Drogan, D.; Joost, H.-G.; Fritsche, A.; Häring, H.-U.; Hrabě de Angelis, M.; Peters, A.; et al. Identification of serum metabolites associated with risk of type 2 diabetes using a targeted metabolomic approach. Diabetes 2013, 62, 639-648. [CrossRef]

132. Mao, X.; Chen, X.; Chen, C.; Zhang, H.; Law, K.P. Metabolomics in gestational diabetes. Clin. Chim. Acta Int. J. Clin. Chem. 2017, 475, 116-127. [CrossRef] [PubMed]

133. Xie, X.; Gao, H.; Zeng, W.; Chen, S.; Feng, L.; Deng, D.; Qiao, F.; Liao, L.; McCormick, K.; Ning, Q.; et al. Placental DNA methylation of peroxisome-proliferator-activated receptor- $\gamma$ co-activator- $1 \alpha$ promoter is associated with maternal gestational glucose level. Clin. Sci. Lond. Engl. 1979 2015, 129, 385-394. [CrossRef] [PubMed]

134. Wu, P.; Farrell, W.E.; Haworth, K.E.; Emes, R.D.; Kitchen, M.O.; Glossop, J.R.; Hanna, F.W.; Fryer, A.A. Maternal genome-wide DNA methylation profiling in gestational diabetes shows distinctive disease-associated changes relative to matched healthy pregnancies. Epigenetics 2018, 13, 122-128. [CrossRef] [PubMed]

135. Aagaard-Tillery, K.M.; Grove, K.; Bishop, J.; Ke, X.; Fu, Q.; McKnight, R.; Lane, R.H. Developmental origins of disease and determinants of chromatin structure: Maternal diet modifies the primate fetal epigenome. J. Mol. Endocrinol. 2008, 41, 91-102. [CrossRef]

136. Suter, M.A.; Chen, A.; Burdine, M.S.; Choudhury, M.; Harris, R.A.; Lane, R.H.; Friedman, J.E.; Grove, K.L.; Tackett, A.J.; Aagaard, K.M. A maternal high-fat diet modulates fetal SIRT1 histone and protein deacetylase activity in nonhuman primates. FASEB J. Off. Publ. Fed. Am. Soc. Exp. Biol. 2012, 26, 5106-5114. [CrossRef]

137. Hjort, L.; Martino, D.; Grunnet, L.G.; Naeem, H.; Maksimovic, J.; Olsson, A.H.; Zhang, C.; Ling, C.; Olsen, S.F.; Saffery, R.; et al. Gestational diabetes and maternal obesity are associated with epigenome-wide methylation changes in children. JCI Insight 2018, 3, 122572. [CrossRef]

138. Haertle, L.; El Hajj, N.; Dittrich, M.; Müller, T.; Nanda, I.; Lehnen, H.; Haaf, T. Epigenetic signatures of gestational diabetes mellitus on cord blood methylation. Clin. Epigenet. 2017, 9, 28. [CrossRef]

139. Weng, X.; Liu, F.; Zhang, H.; Kan, M.; Wang, T.; Dong, M.; Liu, Y. Genome-wide DNA methylation profiling in infants born to gestational diabetes mellitus. Diabetes Res. Clin. Pract. 2018, 142, 10-18. [CrossRef]

140. Elliott, H.R.; Sharp, G.C.; Relton, C.L.; Lawlor, D.A. Epigenetics and gestational diabetes: A review of epigenetic epidemiology studies and their use to explore epigenetic mediation and improve prediction. Diabetologia 2019, 62, 2171-2178. [CrossRef] 